\title{
Changes in Geomorphic Processes in the SNAKE RIVER FOLLOWING IMPOUNDMENT OF JACKSON LAKe AND Potential Changes Due to 1988 FIRES IN THE WATERSHED
}

\author{
RICHARD A. MARSTON $\downarrow$ DEPARTMENT OF GEOGRAPHY \\ UNIVERSITY OF WYOMING $\bullet$ LARAMIE
}

\section{$\checkmark$ OBJECTIVES}

The purpose of this three-year study is to describe, explain and predict changes in the geomorphology of the Snake River (from Jackson Lake Dam to Moose) and related changes in riparian vegetation due to Jackson Lake Dam and 1988 fires in the watershed. Specific objectives are to determine changes over time and space in:

1) sediment mobilization on hillslopes from rainsplash and overland flow;

2) sediment delivery to streams from slope failures;

3) equilibrium condition and relative stability of the Snake River; and

4) extent of various riparian vegetation communities in the Snake River floodplain.

\section{$\checkmark$ METHODS}

The first objective was achieved through a series of rainfall simulation experiments. The methods employed in collecting and analyzing these data were described in the 1990 Annual Report (Marston 1990a). The results related to this project objective were described in 1990 Semiannual Report (Marston 1990b) and have been published by Marston and Haire (1990).

Progress toward acheiving the second objective has been made through 1989 and 1991 field surveys of slope failures which had been originally mapped by the Wyoming Geological Survey. Slope failures were grouped into two types:

1) rapid-shallow failures: including dry debris avalanches and wet debris flows; and

2) slow-deep failures: including blockslides (especially slumps), earthflows, and debris flows.

The field survey methods for this project objective were described in the 1990 Annual Report (Marston 1990a). Only events where the sum of length and width for the failure exceeded 100 meters were utilized, yielding a total 53 slope failures (39 surveyed by 1989 Co-PI Shroder in 1989 and 14 surveyed by 1991 graduate assistant Wrazien in 1991). For each failure, the following data were compiled:

1) type of failure: fast-shallow or slow-deep

2) length, width, depth, volume: from field measurements 
3) underlying bedrock geology: maps by GYCC (1987, map 3)

4) slope gradient: measurement along line from the highest elevation to lowest elevation of the failure on 1:24,000 topographic maps

5) vegetation type: maps by GYCC (1987, map 22)

6) surface area: measurements by electronic planimeter from 1:24,000 topographic maps

The third objective was achieved through analysis of aerial photography and topographic maps combined with field surveys of the $8 \mathrm{~km}$ section of the Snake River from Jackson Lake Dam to Moose Junction. Procedures for mapping the channel and for conducting the stream surveys were described in the 1990 Annual Report (Marston 1990a). The results related to this project objective were described in the 1990 Semiannual Report (Marston 1990b) and have been published by Mills (1991) and Mills and Marston (1990).

Progress toward the fourth objective has been achieved by completing the mapping of floodplain vegetation for 1945 and 1989. The 1989 map was field-checked in August 1991. Landscape diversity was measured for each of five geomorphic reaches between Jackson Lake Dam and Moose, Wyoming, using the Shannon-Wiener function. The procedures and results of this work were described in the 1991 Annual Report (Marston and Mills 1991) with a more complete analysis provided in the thesis by Mills (1991). In the current project year, the planview channel maps (for 1899, 1921, 1945, 1968, 1975, 1983, 1989) and the floodplain vegetation maps (for 1945, 1989) were digitized using ArcInfo. These vector files were then converted to a raster format. The raster grid is 320 cells $\times 220$ cells and each cell has dimensions of $80 \mathrm{~m} \mathrm{x} 80 \mathrm{~m}$, or approximately 0.65 ha. A program was written to determine the years since channel occupance and change in vegetation for any one cell.

\section{- RESUlts}

The mass wasting data have been entered into SPSS where regression analyses will be performed to estimate the volume of slope failures as a function of area and slope gradient. Tests of significance will be undertaken to determine whether regression equations differ between types of slope failures, underlying geologic units, and vegetation. These analyses will be completed by the end of the current project year.

From an overlay of the digitized 1945 and 1989 vegetation maps, Table 1 was derived to show the direction of vegetation change. The total for each row reveals the numbers of cells in each vegetation unit in 1945. The total for each column reveals the number of cells in each vegetation type in 1989. The entries in the matrix reveal how many cells for each vegetation type in 1945 changed or remained the same in 1989.

\section{- CONCLUSIONS}

While vegetation succession is expected from the younger seres $(U, G, S)$ to the forest communities (C, M, B), it is also interesting to note the degree to which forest communities were converted to nonforest communities. By relating these changes to the year of last channel occupance for each cell, it will be possible to determine to what degree channel migration is responsible for vegetation change on the floodplain. Please refer to previous project reports for conclusions regarding other aspects of this multiyear research effort.

\section{- LITERATURE CITED}

Greater Yellowstone Coordinating Committee (GYCC). 1987. An aggregation of national park and national forest management plans. National Park Service and U.S. Forest Service: Washington, D.C.

Marston, R.A. 1990a. Changes in geomorphic processes in the Snake River following impoundment of Jackson Lake and potential changes due to 1988 fires in the watershed. 1990 Semiannual Report submitted to University of Wyoming-National Park Service Research Center: Laramie, WY, 87 pp. (dated 4/16/90)

Marston, R.A. 1990b. Changes in geomorphic processes in the Snake River following impoundment of Jackson Lake and potential changes due to 1988 fires in the watershed. 
Table 1. Matrix of vegetation change along the Snake River from Jackson Lake Dam to Moose, Wyoming: 19451989.

\begin{tabular}{|c|c|c|c|c|c|c|c|}
\hline \multicolumn{3}{|l|}{1945 VEG } & \multicolumn{4}{|c|}{1989 VEGETATION } & \multirow[b]{2}{*}{ TOTAL } \\
\hline UNITS & U & G & S & C & $\mathbf{M}$ & B & \\
\hline $\mathbf{U}$ & 397 & 21 & 25 & 54 & 24 & 0 & 521 \\
\hline G & 97 & 122 & 103 & 270 & 172 & 12 & 776 \\
\hline $\mathbf{s}$ & 37 & 212 & 380 & 660 & 300 & 32 & 1621 \\
\hline C & 24 & 69 & 96 & 254 & 237 & 27 & 707 \\
\hline $\mathbf{M}$ & 14 & 31 & 63 & 46 & 203 & 80 & 437 \\
\hline B & 0 & 11 & 7 & 10 & 7 & 0 & 35 \\
\hline TOTAL & 569 & 466 & 674 & 1294 & 943 & 151 & 4097 \\
\hline $\begin{array}{l}\mathrm{U}=\text { Unve } \\
\mathbf{G}=\text { Grass } \\
\mathrm{S}=\text { Shrub } \\
\mathrm{C}=\text { Low } \\
\mathrm{M}=\mathrm{Mod} \\
\mathrm{B}=\text { High }\end{array}$ & $\begin{array}{l}\text { sits } \\
\text { osits } \\
\text { low-al } \\
\text { nwoo } \\
\text { mixe } \\
\text { spruc }\end{array}$ & $\begin{array}{l}\text { comn } \\
\text { imun } \\
\text { mmun } \\
\text { amun }\end{array}$ & ty & & ue & & \\
\hline
\end{tabular}

1990 Semiannual Report submitted to University of Wyoming-National Park Service Research Center: Laramie, WY, 14 pp. (dated 11/1/90)

Marston, R.A. and Haire, D.H. 1990. Runoff and soil loss following the 1988 Yellowstone fires. Great Plains/Rocky Mountain Geographical Journal 18:1-8.

Marston, R.A. and Mills, J.D. 1991. Changes in geomorphic processes in the Snake River following impoundment of Jackson Lake and potential changes due to 1988 fires in the watershed. 1991 Annual Report submitted to University of Wyoming-National Park Service Research Center: Laramie, WY, 27 pp. (dated $5 / 13 / 91$ )
Mills, J.D. 1991. Wyoming's Jackson Lake Dam, horizontal channel stability, and floodplain vegetation dynamics. M.A. Thesis, Dept. Geography, University of Wyoming: Laramie, WY, 54 pp.

Mills, J.D. and Marston, R.A. 1990. Spatial trends in channel morphology of the Snake River, Grand Teton National Park. Great Plains/Rocky Mountain Geographical Journal 18(1):108-117. 